\title{
Chemical Modification of Spruce Wood with Combination of Mesyl Chloride and Poly ( $\varepsilon$-caprolactone) for Improvement of Dimensional Stability and Water Absorption Properties
}

\author{
*Mahmut A. ERMEYDAN \\ Bursa Technical University, Faculty of Forestry, Department of Forest Industrial Engineering, Bursa \\ *Corresponding author: mahmut.ermeydan@btu.edu.tr
}

Received Date: 03.09.2016

\begin{abstract}
Abstact
Sustainability is an important issue for materials production which can be provided by using renewable resources such as wood. Wood is a natural material with excellent mechanical properties. However, humidity changes negatively affect wood's dimensional stability. Water repellence and dimensional stability can be both improved by inserting hydrophobic molecules inside wood cell walls. In this study, a two-step modification were carried out by grafting a biodegradable polymer poly( $\varepsilon$-caprolactone) (PCL) onto the pre-treated wood cell walls by mesyl chloride. Confocal Raman imaging and spectroscopy were used to show the distribution of mesyl groups and poly( $\varepsilon$-caprolactone) within cell walls. The morphology of modified wood cell walls was monitored by scanning electron microscopy. Physical tests showed that the poly $(\varepsilon-$ caprolactone) grafted wood has significantly better dimensional stability and water repellence compared to references.
\end{abstract}

Keywords: wood modification, mesyl chloride, epsilon caprolactone, polymerization, dimensional stability

Ladin Odununun Boyutsal Stabilitesini ve Su Alma Özelliklerinin İyileştirilmesi için Mesil Klorür ve poli(e-kaprolaton) Kombinasyonu ile Kimyasal Modifikasyonu

Özet

Malzemelerin üretiminde önemli bir konu olan sürdürülebilirlik, ahşap gibi yenilenebilir kaynaklardan elde edilen malzemeler kullanılarak sağlanabilir. Ahşap mükemmel mekanik özelliklere sahip doğal bir malzemedir. Ancak, ortamdaki nem değişimleri ahşabın boyutsal kararlılığını olumsuz etkiler. Hem su iticilik hem de boyutsal kararlılık ahşap hücre çeperi içine hidrofobik moleküller sokulmasıyla arttırılabilir. Bu çalışmada, iki aşamalı bir modifikasyonla önceden mesil klorür ile hidrofobize edilmiş ahşap hücre çeperleri içine biyolojik olarak bozunabilir bir polimer olan poli(e-kaprolakton) (PCL) aşı polimerizasyonuyla bağlandı. Konfokal Raman görüntüleme ve spektroskopisi tekniğiyle ahşap hücre çeperleri içindeki mesil grupları ve poli( $\varepsilon$-kaprolakton) dağılımını gösterildi. Modifiye edilmiş ahşap hücre çeperlerinin morfolojisi taramalı elektron mikroskobu ile gözlemlendi. Fiziksel testler sonucunda poli( $\varepsilon-$ kaprolakton) ile aşılanmış ahşabın referanslara göre önemli ölçüde daha iyi boyutsal kararlılığa ve su iticiliğe sahip olduğu gözlendi.

Anahtar kelimeler: ahşap modifikasyonu, mesil klorür, epsilon kaprolakton, polimerizasyon, boyutsal stabilite

\section{Introduction}

Wood is one of the primary building materials due to its fine properties such as having good mechanical properties, being a renewable raw material, process ability, light weight, aesthetic appearance, and sustainability (Fengel and Wegener, 1984; Rowell, 2005; Hill, 2006). Long-lasting wood material and less problematic recycling of wood are important arguments towards creating sustainable and environmental-safe wood products (Ermeydan et al. 2014). 
(a)

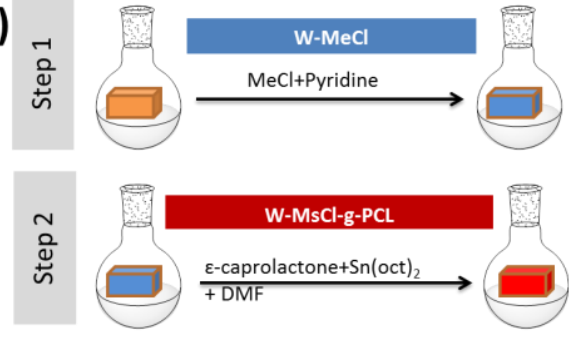

(b)

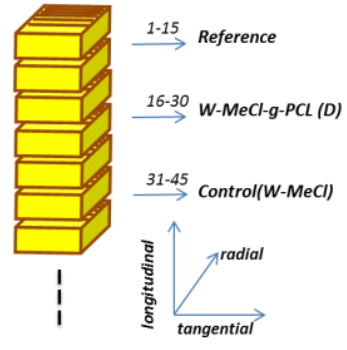

(c)

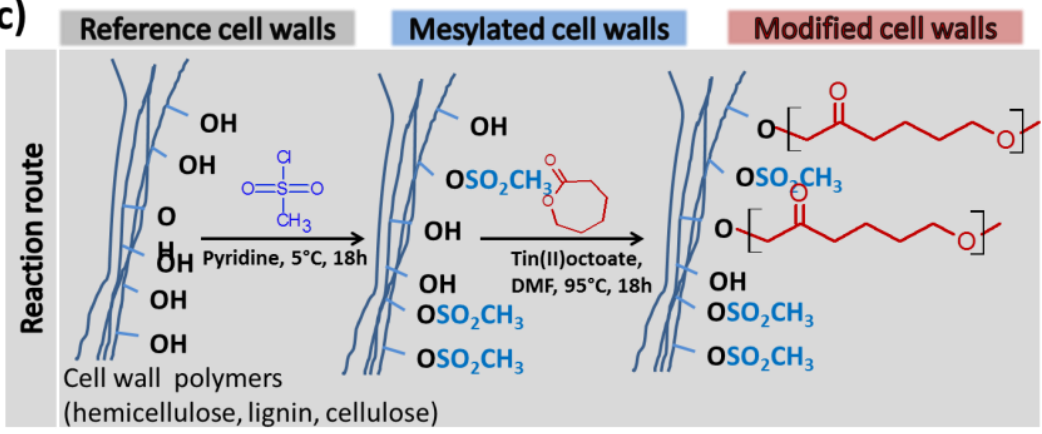

Figure 1. (a) Reaction route of mesylation and polycaprolactone grafting on the cell wall polymers (b) Demonstration of wood sampling before modification (c) Reaction schema of mesylation and polycaprolactone grafting onto wood cell wall polymers.

However, because of the hydrophilic structure of cell wall polymers, wood has some negative properties. These negative properties restrict long term utilization of wood as a building material. Hygroscopic nature of wood cell walls causes large amount of water or moisture absorption into the wood from the atmosphere (Gibson, 2012). Water absorption swells and water desorption shrinks the wood cell walls. This phenomenon may happen during a day by humidity changes of the environment. The mechanical movement of the cell walls by swelling and shrinking consequently leads to dimensional instability which may deform the wood material (Fengel and Wegener, 1984; Rowell, 2005; Hill, 2006). Another issue is decay problem of wood by fungal attack which is propagated by presence of water or high humidity in wood (Schirp and Wolcott, 2005; Hill, 2006). Wood modification studies generally focus on reduction of water uptake of wood to increase decay resistance. Some modification methods may increase also wood dimensional stability (Hill, 2006). In order to make considerable increase in dimensional stability and other wood properties, chemicals have to be inserted and fixed inside the wood cell walls (Furuno et al., 2004; Rowell, 2005; Hill, 2006). For example, reaction of reagents such as anhydrides, chlorides, cyanates by forming covalent bonds between hydroxyl groups of wood polymers is a well-studied approach (Rowell, 1984; Donath et al., 2004). Other approach for wood modification is in-situ grafting polymerization of monomers (Rowell, 2005; Hill, 2006; Nordstierna, 2008; Ermeydan et al., 2014). Wood cell wall modification has a lot of limits such as use of moderate reaction conditions to avoid cell wall deformation and harmful sideproducts. Besides, due to the hygroscopic structure of the cell walls, introduction of hydrophobic chemicals has limited opportunity, while impregnation of small molecules solubilized in polar solvents like water penetrates cell walls. In-situ polymerization of hydrophobic monomers 
inside wood has been studied several times because hydrophobic molecules have potential to repel water more compared to hydrophilic molecules. Thus, if wood can successfully be modified with hydrophobic molecules/polymers, leaching of those chemicals by washing will be very limited. Few of the studies reported successful modification with hydrophobic polymers in the cell walls, and few of them results an efficient and stable improvement of dimensional stability (Furuno and Goto 1979; Nakagami and Yokota, 1983; Ermeydan et al. 2014a, 2014b; Cabane et al., 2014, Keplinger et al. 2015). Recently, Ermeydan et al. reported a wood pretreatment method that enhances the introduction of hydrophobic molecules in the cell wall (Ermeydan et al, 2012; 2014a). Hydrophobic flavonoid molecules were successfully inserted inside the pretreated cell walls. Modified wood material had reduced water/moisture uptake and increased dimensional stability. The "pretreatment" of the cell walls were achieved by reacting some of the $-\mathrm{OH}$ groups from the wood polymer network with tosyl chloride. This chemical pre-treatment was hydrophobized wood cell walls, thus penetration of hydrophobic molecules improved in the second step. The reaction conditions used for the two-step modification treatment were suitable for wood modification compared to other techniques. Additionally, Ermeydan et al. (2014b) reported on a direct wood modification in one step by hydrophobic epsilon-caprolactone monomer grafting on cell wall polymers to form biodegradable polycaprolactone polymer inside the cell wall structure. Aim of that study was to improve wood properties with biodegradable polymers to make a product that will not create recycling problems. By this method Ermeydan achieved to reduce equilibrium moisture content (EMC) about
$30 \%$ and found an anti-swelling efficiency (ASE) about $40 \%$.

In this study a different pre-treatment reagent, methane sulfonyl chloride (mesyl chloride) was used instead of tosyl chloride which was used in the previous studies (Ermeydan et al., 2012; 2014a). Mesyl chloride is a reactive reagent that reacts with $-\mathrm{OH}$ groups. Mesyl chloride is a smaller molecule than tosyl chloride, thus our aim was to react more $-\mathrm{OH}$ groups of cell wall polymers which may provide to insert more hydrophobic monomer inside the wood cell walls. Following this pre-treatment, here a hydrophobic monomer (epsiloncaprolactone) was successfully grafted into the wood cell walls. Polycaprolactone (PCL) for the first time has been used to modify solid wood material without a pretreatment by our research group (Ermeydan et al., 2014b). In that study it was observed that PCL has a potential to modify wood in terms of dimensional stability (40\% ASE) and water repellence $(40 \%)$. Also PCL grafted wood may have an opportunity to eliminate recycling problems of wood polymer composites. In this study PCL chains were fixed within the pre-treated cell wall structure. Dimensional stability (25\% ASE) and water repellence (50\% reduction) of the modified wood are considerably improved; however morphologic analysis showed that there is more deformation of the cell walls compared to references.

\section{Methods and Materials}

Materials: Methylsulfonyl chloride (Mesyl Chloride - $\mathrm{MsCl}$ ), $\varepsilon$-caprolactone (CL), pyridine, tin(II) octoate $\left(\mathrm{Sn}(\mathrm{oct})_{2}\right)$, acetone, dry dimethyl formamide (DMF) were bought from $\mathrm{SiAl}$ and used as received.

Modification of wood samples: Fourty five Norway spruce (Picea abies) sapwood sample $(1 \mathrm{~cm} \times 1 \mathrm{~cm} \times 0.5 \mathrm{~cm}$; radial $\mathrm{x}$ tangential $\mathrm{x}$ longitudinal) were cut along the grain, and dried at $63^{\circ} \mathrm{C}$ over night. The samples were divided in three sets of 
fifteen cubes: one set as reference (i.e. untreated), one set as control (only mesylated), and one set as full modification (mesylated + polycaprolactone grafted). After modification step, ten samples from each set were used to make physical characterization (i.e. water uptake (WU), leaching, swelling (S), anti-swelling efficiency (ASE) tests). The rest of the samples were used for SEM and Raman analysis. Experimental workflow and reaction route is given in Figure 1.

Mesylation of wood samples: Wood samples were weighed $(0,95 \mathrm{~g}, 5,86 \mathrm{mmol}$ - calculated as a glucopyranose equivalent, AGU, MW: $162 \mathrm{~g} / \mathrm{mo} 1) .50 \mathrm{ml}$ of dry pyridine was added to the samples in the reaction flask for wood swelling overnight. Equivalent molar amount of methane sulfonyl chloride $(0,67 \mathrm{~g}, 5,86$ mmol (MW:114,55 g/mol)) was added onto pyridine and wood mixture and waited for reaction by stirring for $18 \mathrm{~h}$ at $5^{\circ} \mathrm{C}$ (ice bath).

Impregnation and grafting polymerization of $\varepsilon$-caprolactone: Mesylated wood samples were washed a couple of times with DMF. Then a solution of $20 \mathrm{~g} \varepsilon-$ caprolactone with $0,2 \mathrm{~g}$ initiator $\mathrm{Sn}(\mathrm{Oct})_{2}$ were rinsed onto wood samples and samples were kept in the overnight to increase impregnation of monomer into cell walls before polymerization reaction. On the other day, dry DMF $(20 \mathrm{ml})$ were poured into the reaction media and argon was used to degas reaction solution by bubbling for $30 \mathrm{~min}$. Polymerization was carried out at $95^{\circ} \mathrm{C}$ (overnight). Reaction was completed by starting acetone washing with many portions of acetone for 4 hours, and then with distilled water (overnight). At the end, wood samples were dried at $63^{\circ} \mathrm{C}$ (overnight). DMF and acetone which were used for polymerization and washing process are good enough for dissolving both polycaprolactone and $\varepsilon$-caprolactone monomer.

\section{Material Characterization}

Scanning Electron Microscopy (SEM): Morphological details of the reference and modified wood samples were monitored using an (E)SEM device (FEI FEG-ESEM Quanta 600, FEI Company, Hillsboro, OR, USA) with a backscattered electron (BSE) detector operated at $7.5 \mathrm{kV}$ with a $10 \mathrm{~mm}$ sampledetector distance, 0.75 Torr pressure and $4.0 \mathrm{~nm}$ spot size.

Raman Analysis: $30 \mu \mathrm{m}$ cross-sections were cut with a rotary microtome (LEICA RM2255, Germany) in a region 1-2 mm below the surface of the wood samples. To maintain wood slice wet, with a drop of water, the slice were put between a glass microscope slide and coverslip. A confocal Raman microscope (alpha300, WITec GmbH, Ulm, Germany) equipped with an objective $(60 \mathrm{X}, \mathrm{NA}=0.8,0.17 \mathrm{~mm}$ coverslip correction from Nikon Instruments, Amstelveen, The Netherlands) was used to collect Raman spectra with A $532 \mathrm{~nm}$ laser (Crysta Laser, Reno, NV, USA) was focused with a diffraction limited spot size of $0.61 \lambda / \mathrm{NA}$ and the Raman signal was detected with an air cooled back illuminated CCD camera (DV401-BV, Andor, Belfast, North Ireland) behind the spectrograph (UHTS 300 , WITec) with a spectral resolution of $3 \mathrm{~cm}^{-1}$. To plot Raman maps, $0.4 \mathrm{~s}$ integration time was used. Twodimensional chemical images of the wood polymers and additional materials (mesyl groups and polycaprolactone) were compiled using WitecProject software with the integration filter tool. 


\begin{tabular}{|c|c|c|}
\hline$S(\%)=\frac{\left(V_{i}-V_{i i}\right)}{V_{i i}} \times 100$ & $\operatorname{ASE}(\%)=\frac{S_{u m}-S_{m}}{S_{u m}} \times 100$ & $W U(\%)=\frac{\left(w_{i i}-w_{i}\right)}{w_{i}} \times 100$ \\
\hline $\begin{array}{l}\text { where } \mathrm{S}(\%) \text { : volumetric swelling; } \\
\mathrm{V}_{\mathrm{i}}: \text { wood volume after wetting } \\
\text { with liquid water; } \mathrm{V}_{\mathrm{ii}} \text { : wood } \\
\text { volume of oven-dried samples } \\
\text { before wetting }\end{array}$ & $\begin{array}{l}\text { where ASE(\%): antishrinking/antiswelling } \\
\text { efficiency resultin from the modification; } \\
\mathrm{S}_{\mathrm{m}} \text { : modified volumetric swelling } \\
\text { coefficient; } \mathrm{S}_{\mathrm{um}} \text { : unmodified volumetric } \\
\text { swelling coefficient. }\end{array}$ & $\begin{array}{l}\text { where } \mathrm{WU}(\%) \text { : percentage of } \\
\text { water uptake of the samples; } \mathrm{w}_{\mathrm{i}} \text { : } \\
\text { initial weight of the sample; } \mathrm{w}_{\mathrm{ii}} \text { : } \\
\text { wet weight of the sample after } \\
\text { water-soaking }\end{array}$ \\
\hline
\end{tabular}

Figure 2. Equations of Swelling (S), Antiswelling efficiency(ASE), Water Uptake (WU).

Weight Percentage Gain (WPG) and Volume Change: To find out weight and volume changes caused by the chemical treatments, weights and dimensions of the wood samples were measured before and after each treatment (mesylation, caprolactone polymerization, water immersion, and oven drying).

Water Uptake (WU), Mass Loss, Swelling Coefficient (S), and AntiSwelling Efficiency (ASE): The reference, mesylated and fully modified wood samples were soaked into distillated water for five days with a fair shaking (Soak cycle 1). Then samples were dried into an oven at $103^{\circ} \mathrm{C}$ over night (Drying cycle 1). Samples were soaked again into distilled water for the second watersoaking and drying cycles. The dimensional stability of the modified wood samples was obtained by calculating the $S$ and the ASE values as reported (Rowell and Ellis, 1978). The equations for swelling, anti-swelling efficiency, and WU calculations are given in Figure 2. The water repellence ability of modified wood is described by the WU calculations.

\section{Results and discussion}

Mesylation of the wood cell walls: Use of mesyl chloride for wood modification has not been used before. Mesyl chloride is generally used in organic chemistry as a leaving group on hydroxyl groups to be substituted later by nucleophilic chemicals (Netscher and Bohrer, 2002). However, a similar chemical reagent, tosyl chloride, has been used recently by Ermeydan et al. (2012) to hydrophobize interior of wood cell walls by reaction and blocking of some hydroxyl groups on the wood polymers. In this manuscript, mesylation was carefully carried out to hydrophobize wood cell walls to be able to impregnate more hydrophobic $\varepsilon$-caprolactone monomer for further graft polymerization (Ermeydan et al., 2014b). The weight percent gain (WPG $\%$ ) and volume change of mesylated wood (Me-Wood) is shown in Table 1. Mesylation increased the weight of the wood samples by $9 \%$ while volume of the wood blocks reduced about $1 \%$. Increase in WPG\% shows that mesyl chloride successfully reacts with wood polymers; however decrease of wood volume may indicate a critical degradation of the wood cell structure by mesylation.

Polycaprolactone grafting in the mesylated wood: $\varepsilon$-caprolactone can be polymerized to obtain polycaprolactone by ring-opening polymerization (ROP), generally catalyzed with metal based catalysts (poor metals such as aluminum and tin based catalysts, alkaline earth metals, transition metals, and rare earth metals) (Storey and Sherman, 2002; Wiltshire and Qiao, 2006), but also organic catalytic systems or enzymatic (Labet and Thielemans, 2009). Hydroxyl groups in the reaction media can act as coinitiators for the polymerization which proceeds through in-situ formed activated stannous alkoxide species. 
Table 1. Weight percentage gain and volume changes of spruce wood samples after mesylation and ring opening polymerization reactions (Me-Wood: Mesylated wood samples, Me-W-g-PCL: Mesylated and after polymer grafted wood samples).

\begin{tabular}{|l|c|c|}
\hline Exp ID & WPG (\%) & Volume Change (\%) \\
\hline Me-Wood & 9,84 & $-0,71$ \\
\hline Me-W-g-PCL & 22,3 & 4,18 \\
\hline
\end{tabular}

The hydroxyl groups of carbohydrates like cellulose were already used as initiators for the ring-opening polymerization of caprolactone. Thus PCL grafted cellulose can be obtained (Lönnberg et al., 2006; Kusumi et al., 2011). The aim of this study was to use reachable hydroxyl groups present in the wood cell wall polymers (cellulose, lignin, and hemicellulose) to start polymerization of $\varepsilon$-caprolactone and obtain wood grafted with PCL. $\varepsilon$-caprolactone penetration in the cell wall structure is a challenging step due to hydrophobic structure of monomer. It is thought that a pre-treatment with mesyl chloride would improve $\varepsilon$ caprolactone penetration as reported by Ermeydan et al. (2012). Also DMF was used as reported (Ermeydan et al., 2012) which swells wood to a greater extent (Mantanis et al., 1994). The WPG and volume changes resulting from the grafting of PCL onto Me-Wood (Me-W-gPCL) are summarized in Table 1.

The weight percentage gain (WPG \%) and volume change that were measured and calculated after PCL synthesis help us to understand the success of the modification. The highest WPG\% and volume change after polymer modification belongs to $\mathrm{Me}-\mathrm{W}-g$-PCL samples. The increase in dimensions of $\mathrm{Me}-\mathrm{W}-\mathrm{g}-\mathrm{PCL}$ samples may indicate the presence of polymer within the wood cell wall. It is known that after a successful modification, positive volume change is mostly because of additional materials that fill the cell wall (Ermeydan et al., 2014b; Hill and Ormondroyd, 2004; Schneider and Brebner, 1985). Mesylation itself made about 9\% WPG and a negative volume change. The negative volume change means there is a lot more cell wall material was removed than the additional mesyl groups due to the acidity of the reactivity and acidity of mesylation process.

Polymer distribution in cell wall: Mesyl chloride is a reactive reagent and it is impossible to observe it spatially after reaction with cell wall polymers. But, polycaprolactone polymer can be observed in the lumen if exists.

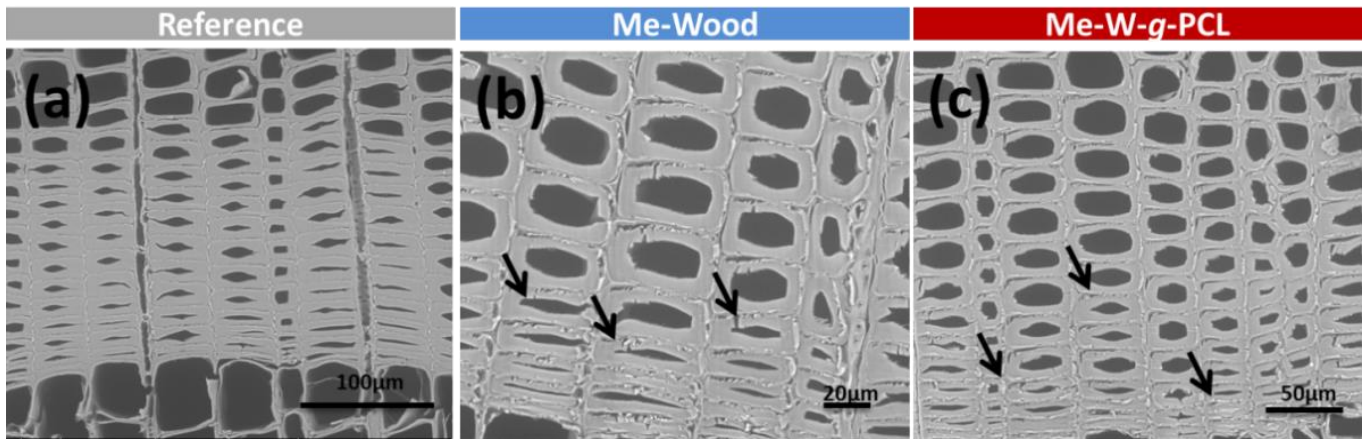

Figure 3. SEM images of microtomed cross-sections (a) untreated cell walls (b) MeWood (i.e. treated with mesyl chloride in pyridine at $5^{\circ} \mathrm{C}$ ), (c) Me-W-g-PCL: in-situ polycaprolactone grafted on mesylated cell walls in DMF. 


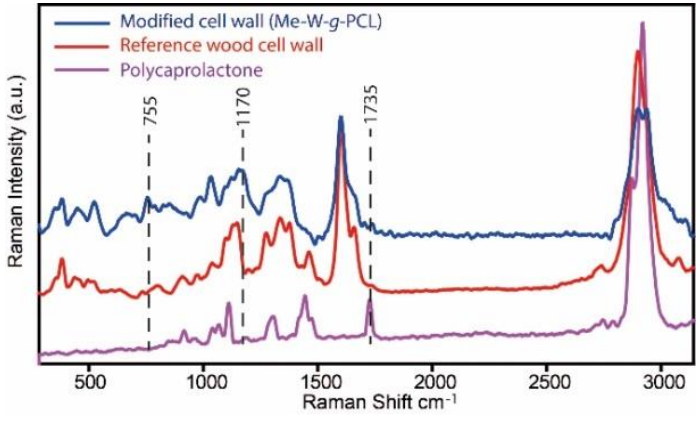

Figure 4. Raman spectrum of poly caprolactone grafted mesylated cell walls Me-W-g-PCL compared with reference wood and polycaprolactone spectra in the $400-3200 \mathrm{~cm}^{-1}$ spectral range.

The spatial distribution of polycaprolactone at cross-section of wood tissues was determined by using a SEM device. SEM images of reference cell walls are shown in Figure $3 a$. Figure $3 b$ shows that Me-wood has some noticeable cell wall deformations in the cell walls and between cell lamella, which indicates that the mesylation process affect the wood tissue microstructure. In Figure 3c, Me-Wg-PCL is shown, there is still some deformation can be observed from the initial mesylation process, but no more degradation can be figured out due to polycaprolactone polymerization (Ermeydan et al., 2014b).

In the polymerization process, wood samples were soaked into monomer/DMF solution, and that's why polymerization in the cell lumina is also expected. This is because of the existence of any water molecules in the solution which also may limit initiation of caprolactone polymerization starting from the cell wall hydroxyls. Fortunately, the free PCL polymers if any in solution or in the cell lumina were washed away with acetone after modification. In Figure $3 c$ it is indicated that the cell lumina are empty which also shows that for the sample MeW-g-PCL, all weight was gained by the cell walls.

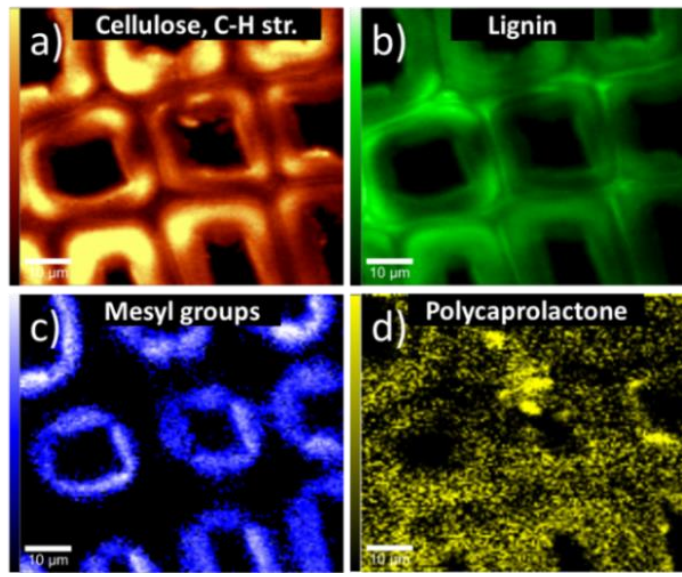

Figure 5. Raman images (a-d: 70x60 $\mu \mathrm{m}^{2}$ ) of latewood cell wall tissue. Images were plotted by integration of Raman bands from spectral data set a) $\mathrm{C}-\mathrm{H}$ stretching groups $\left(2850-3010 \mathrm{~cm}^{-1}\right), \mathrm{b}$ ) lignin $\left(1555-1660 \mathrm{~cm}^{-1}\right)$, and c) mesyl groups $\left.\left(750-800 \mathrm{~cm}^{-1}\right), \mathrm{d}\right)$

polycaprolactone carbonyl group (1705$1755 \mathrm{~cm}^{-1}$ ).

Addition to the electron microscopy analysis, chemical changes in the mesylate and polycaprolactone grafted cell walls structure was investigated. By chemical characterization, chemical fingerprints of the mesyl groups and polycaprolactone within the cell walls were found. In this point of view, a rather advance method, Confocal Raman Microscopy, is used as a powerful technique for the detailed analysis of plant cell walls that provides spectroscopic output of cell wall. Raman Microscopy can also be used to build chemical images of the many materials including wood (Butler et al., 2016; Gierlinger et al., 2007; Keplinger et al., 2015; 2016). Typical Raman spectra of reference wood, polycaprolcatone polymer and Me-W-g-PCL are shown in Figure 4. In the Raman spectra of polycaprolactone grafted cell walls, fingerprints of wood bands can be clearly observed (Gierlinger et al., 2007). 
In the spectrum of $\mathrm{Me}-\mathrm{W}-\mathrm{g}-\mathrm{PCL}$ sample, except from the wood Raman bands, some additional strong bands were observed in the $755 \mathrm{~cm}^{-1}, 1100-1200 \mathrm{~cm}^{-1}$, $1400-1500 \mathrm{~cm}^{-1}$ and $1700-1750 \mathrm{~cm}^{-1}$ regions. $755 \mathrm{~cm}^{-1}$ and $1170 \mathrm{~cm}^{-1}$ bands belong to $\mathrm{S}-\mathrm{C}$ and $\mathrm{SO}_{2}$ symmetric stretching respectively due to mesyl groups (Hanai and Okuda, 1975). As shown in Figure 4, polycaprolactone has strong bands between 1400-1500 $\mathrm{cm}^{-1}$ which belong to $\delta\left(\mathrm{CH}_{2}\right)$ vibrations and a strong band at $1725 \mathrm{~cm}^{-1}$ which belongs to $v(\mathrm{C}=\mathrm{O})$ vibration (Kister et al., 2001). In the Raman spectrum of fully modified cell walls, a clear signal related to the presence of $-\mathrm{CH}_{2}-$ groups from PCL cannot be observed, also wood signals related to lignin. This is due to fluorescence problem occurred during Raman scanning. But, the $\mathrm{C}=\mathrm{O}$ bonds on the PCL polymer can be observed. These polyester peaks were clearly absent in the reference wood samples. In the study reported at Ermeydan et al. (2014), Raman intensity of the signals from the polycaprolactone was higher because amount of polycaprolactone in the cell walls was higher (17\% WPG). However, in this study we found that polycaprolactone itself increased weight of the cell walls about $13 \%$. This value is low than reported value, because use of mesylation in this study already reacted some of the reactive $-\mathrm{OH}$ groups in the cell walls and thus caprolactone monomers found limited $\mathrm{OH}$ groups to react.

In Figure 5, Raman images of a latewood cross-section from mesylated and PCL grafted cell walls which were obtained via lazer scanning of wood surface are shown. This surface scans can be compiled to create colorful Raman images by integration of the interested peaks for wood polymers, mesyl groups and polycaprolactone found in the spectra (see methods part). In Figure 5, image a) represents the $\mathrm{CH}$-groups (mainly from cellulose) and the lignin distributions are shown in image b), indicating the overall cell wall structure. Bright orange zones illustrate mainly cellulose distribution in the secondary cell wall, where bright green zone illustrates the lignin in the cell corners and in compound middle lamella. Mesyl group distribution can be observed in the cell walls (bright blue zones) but not in the cell corners or compound middle lamella. This phenomenon is similar as tosyl chloride treatment which was reported by Ermeydan et al. (2012). It can be concluded that the sulfonyl chlorides cannot be pass thorough and go deeper in the cell walls. The polycaprolactone
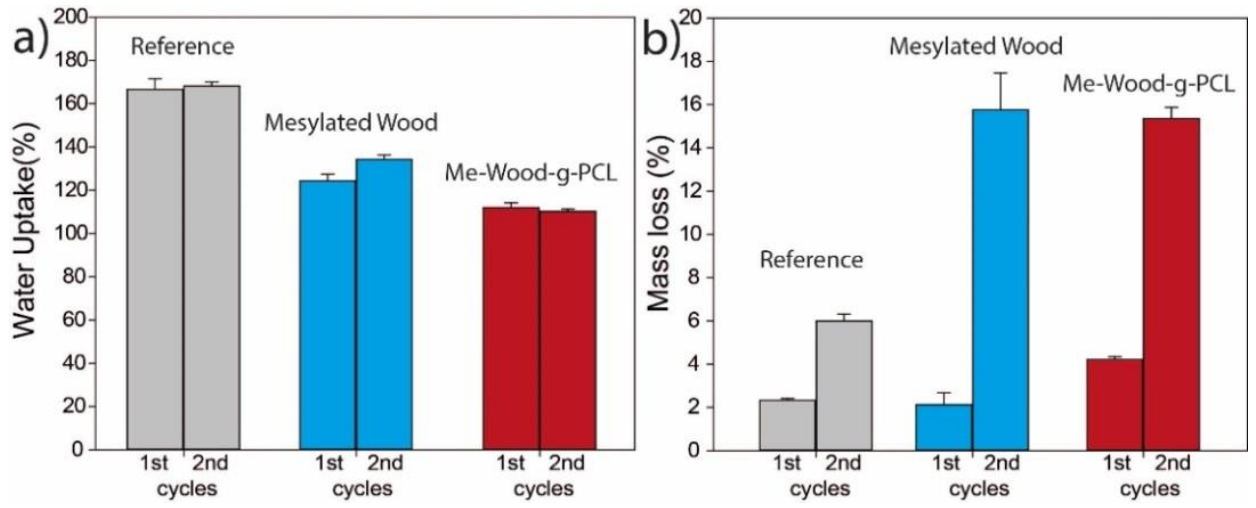

Figure 6. a) WU values for reference wood, mesylated wood(Me-wood), fully modified wood (Me-W-g-PCL. b) Total mass loss due to leaching of unbound material after the samples were immersed in water for five days (1st cycle), and after another five days ( 2 nd cycle). 

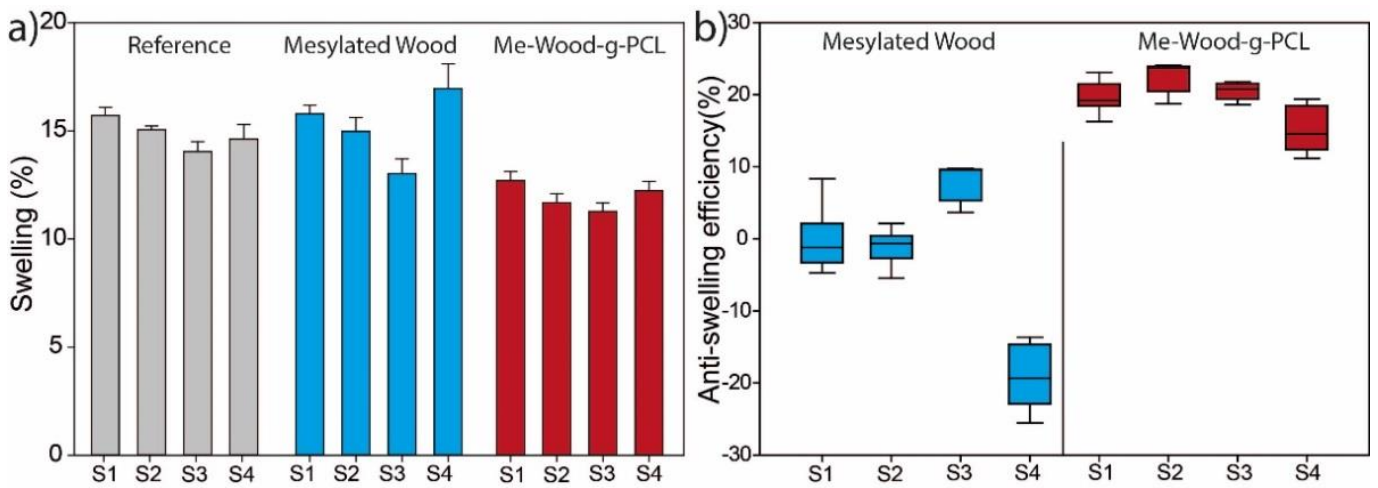

Figure 7. a) Average swelling values from the water soaking and oven drying cycles. b) ASE values for treated wood samples (Me-Wood, Me-W-g-PCL).

distribution of polymer grafted cell walls (Me-W-g-PCL in Figure 5d) indicates that polymerization took place in the cell walls (yellow zones). The polycaprolactone is predominantly located in a cell wall region close to the lumen and some pits. Images clearly show that the penetration of the mesyl groups and caprolactone monomer (consequently the polymer) inside the cell wall can be achieved.

Improved Wood Properties: To determine improvements in WU (water uptake) properties and dimensional stability of the Me-wood and Me-W-gPCL wood samples, we operated watersoaking method developed by Rowell et al. (1978). In this method wood samples are soaked in water and dried for several subsequent cycles and at each step a measurement protocol is carried out to find efficiency of wood modification treatments by the determination of WU and dimensional stability changes compared to references.

Water uptake and stability of polymers in wood: The WU of the samples (after two water immersion cycles) is shown in Figure 5a. Reference wood sample gained about $165 \%$ weight after five days (1st cycle), while Me-wood and Me-W-g-PCL gained about $125 \%$ and $110 \%$, respectively. After the second immersion cycle, similar results were found. As expected, mesylation already decrease water uptake by $25 \%$, where the total water uptake after hydrophobic polycaprolactone grafting decrease water sorption by $33 \%$. Polycaprolactone itself made a small decrease of water absorption. This is related to the mesylation step. Mesyl chloride already reacted with free hydroxyl groups on the cell wall polymers, thus in the second step polycaprolactone can limitedly enter inside the cell walls. Consequently water repellence effect of PCL is seemed to be low.

Modified wood, even untreated wood loses weight during repeated water soaking-oven drying cycles due to the removal of extractives and non-bound modifying compounds (Ermeydan et al., 2014). The mass losses calculated for the reference (untreated), Me-wood and Me$\mathrm{W}$-g-PCL samples are given in Figure $5 b$. The mass loss of reference wood and both mesylated and polymerized wood samples are significantly different. As it is known the reference wood may lose extractives during the water soaking-oven drying cycles, but for the modified samples, especially in the second cycle lost about $15 \%$ weight. This is most probably related to the destructive process of the mesylation step; because mesylation process slightly degrade cell walls as discussed above with SEM analysis (Figure 3). Ermeydan et al. (2014) reported that polycaprolactone modification itself 
do not make such weight loses because the additional material in the modified wood is locked within the wood structure by polymer network. However in this case, mesylated and polimerized (Me-W-gPCL) wood samples lost considerable weight due to mesylation degraded cell walls.

Dimensional stability of mesylated and polymer grafted wood: The improvement of dimensional stability of the Me-Wood and Me-W-g-PCL samples were evaluated by conventional water soaking-oven drying method as described in methods part. The swelling and shrinkage difference of the wood samples according to references were calculated as $S$ and then ASE were calculated according to the equations given in the methods (Figure 2).

By change in humidity of the environment wood cell walls swell or shrink which result as volume change of the bulk wood material. Depending on the species or type of the cell, untreated wood may swell about $15-20 \%$. In case of a polymer modification of wood with hydrophobic materials, those materials bulks the cell wall and wood material may repel water due there will be less space for the water molecules into the cell walls. Consequently, swelling of wood material decreases. High dimensional stability values can be achieved by low swelling values. As shown in Figure $7 \mathrm{a}$, the swelling of the volumetric $S$ values of the reference is about $15 \%$ at all water soaking-oven drying cycles. However, volume of mesylated wood shows an instable trend and in the last cycle increases up to $18 \%$ due to the harsh chemical process of mesylation. Volumetric $\mathrm{S}$ values of $\mathrm{Me}-\mathrm{W}-\mathrm{g}-\mathrm{PCL}$ samples are reduced $12 \%$ levels which already show the first indication of better dimensional stability.

The volumetric swelling $S$ already indicates the scope of dimensional stability but the ASE depicts one step more and simply compares the swelling of reference wood with modified wood. High ASE values represent high dimensional stability (see Figure 2 for equations). As shown in Figure $7 \mathrm{~b}$, starting from zero, and instable trend which ends with $20 \%$ negative ASE of mesylated samples may be explained by the removal of already degraded cell wall polymers (lignin/hemicelluloses) by swelling-drying cycles which occurs space in the cell walls and enhanced swelling. Unlike mesylated wood, the ASE values of Me-W-g-PCL samples are around 20\% after each water soaking and oven drying cycle, that shows the polycaprolactone is effective even after mesylation and increases the dimensional stability of wood. Unfortunately in the last cycle, ASE of M-W-g-PCL samples decreased probably due to the already damaged cell wall components mechanically removed by swelling-shrinking cycles.

\section{Conclusions}

Here, mesylation of wood and two step modification of wood with effective polycaprolactone polymerization were reported for the first time. The hydroxyl groups were targeted to functionalize cell walls by mesyl chloride and further $\varepsilon$ caprolactone were polymerized to obtain a double effect and to increase properties of wood. Indeed polycaprolactone showed an increment in dimensional stability, however we found that mesylation process degrade cell wall slightly and has no positive effect on ASE. Still mesylation provide some water repellence of wood because mesyl chlorides block hydroxyl groups of wood polymers and reduces hygroscopic character of the cell wall. As a result, using a biodegradable synthetic polymer like polycaprolactone, production of a novel wood material with improved properties was studied. This new material is believed to have also environmental advantages like being easily disposed. 


\section{Acknowledgements}

I thank Bursa Technical University, Turkey as well as the Max Planck Institute of Colloids and Interfaces, Germany for providing laboratory equipment and financial support.

\section{References}

Butler, H.J., Ashton, L., Bird, B., Cinque, G., Curtis, K., Dorney, J., Esmonde-White, K., Fullwood, N.J., Gardner, B., Martin-Hirsch, P.L., Walsh, M.J., McAinsh, M.R., Stone, N., and Martin, F.L. 2016. Using Raman spectroscopy to characterize biological materials, Nature Protocols, 11, 664-687.

Cabane, E., Keplinger, T., Merk, V., Hass, P. and Burgert, I. 2014. Renewable and functional wood materials by grafting polymerization within cell walls, ChemSusChem, 7(4), 1020 1025.

Donath, S., Militz, H., and Mai, C. 2004. Wood modification with alkoxysilanes, Wood Science and Technology, 38, 555-566.

Ermeydan, M.A., Cabane, E., Gierlinger, N., Koetz, J. and Burgert, I. 2014. Improvement of wood material properties via in situ polymerization of styrene into tosylated cell walls, RSC Advances, 4, 12981-12988.

Ermeydan, M.A., Cabane, E., Hass, P., Koetz, J., and Burgert, I. 2014. Fully biodegradable modification of wood for improvement of dimensional stability and water absorption properties by poly( $\varepsilon$-caprolactone) grafting into the cell walls, Green Chemistry, 16, 3313-3321.

Ermeydan, M.A., Cabane, E., Masic, A., Koetz, J. and Burgert, I. 2012, Flavonoid Insertion into Cell Walls Improves Wood Properties, ACS Applied Materials and Interfaces, 4, 5782-5789.

Fengel D. and Wegener, G. 1984. Wood: Chemistry, Ultrastructure, Reactions, ISBN 311-008481-3, W. de Gruyter, Berlin/New York.

Furuno, T. and Goto, T. 1979. Structure of the interface between wood and synthestic polymer. XII. Distribution of styrene polymer in the cell wall of wood-polymer composite(WPC) and dimensional stability, Mokuzai Gakkaishi, 1979, 25, 488-495.

Furuno, T., Imamura, Y., and Kajita, H. 2004. The modification of wood by treatment with low molecular weight phenolformaldehyde resin: a properties enhancement with neutralized phenolic-resin and resin penetration into wood cell walls, Wood Science and Technology, 37, 349-361.

Gibson, L.J. 2012. The hierarchical structure and mechanics of plant materials, Journal of Royal Society Interface, 9(76), 2749-2766.

Gierlinger, N., and Schwanninger, M. 2007. The potential of Raman microscopy and Raman imaging in plant research, International Journal of Spectroscopy, 21, 69-89.

Hanai, K., Okuda, T., and Machida, K. 1975. Vibrational spectra of methane sulfonyl chloride and methane sulfonyl chloride-d3, Spectrochimica Acta, 31A, 1227-1232.

Hill, C.A.S., and Ormondroyd, G.A. 2004. Dimensional changes in Corsican pine (Pinus nigra Arnold) modified with acetic anhydride measured using a helium pycnometer, Holzforschung, 58, 544-547.

Hill, C.A.S. 2006. Wood Modification: Chemical, Thermal and Other Processes, ISBN: 978-0-470-02172-9, John Wiley \& Sons, Chichester, England; Hoboken, NJ.

Keplinger, T., Cabane, E., Berg, J.K., Segmehl, J.S., Bock, P., and Burgert, I. 2016. Smart Hierarchical Bio-Based Materials by Formation of Stimuli-Responsive Hydrogels inside the Microporous Structure of Wood, Advance Materials Interfaces, 3, 1600233.

Keplinger, T., Cabane, E., Chanana, M., Hass, P., Merk, V., Gierlinger, N., Burgert, I. 2015. A versatile strategy for grafting polymers to wood cell walls, Acta Biomaterialia, 11, 256263.

Kister, G., Cassanas, G., Bergounhon, M., Hoarau, D., and Vert, M. 2000. Structural characterization and hydrolytic degradation of solid copolymers of D,L-lactide-co-epsiloncaprolactone by RAman spectroscopy, Polymer, 41, 925-932.

Kusumi, R., Teramoto, Y., and Nishio, Y. 2011. Structural characterization of poly( $\varepsilon$ caprolactone)-grafted cellulose acetate and butyrate by solid-state 13C NMR, dynamic mechanical, and dielectric relaxation analyses, Polymer, 52, 5912-5921.

Labet, M., and Thielemans, W. 2009. Synthesis of polycaprolactone: a review, Chemical Society Reviews, 38, 3484-3504.

Lönnberg, H., Zhou, Q., Brumer, H., Teeri, T.T., Malmstrom E., and Hult, A. 2006. Grafting 
of cellulose fibers with poly(epsiloncaprolactone) and poly(L-lactic acid) via ringopening polymerization, Biomacromolecules, 7 , 2178-2185.

Makiguchi, K., Satoh, T., and Kakuchi, T. 2011. Diphenyl Phosphate as an Efficient Cationic Organocatalyst for Controlled/Living Ring-Opening Polymerization of $\delta$ Valerolactone and $\varepsilon$-Caprolactone, Macromolecules, 44, 1999-2005.

Mantanis, G.I., Young, R.A., and Rowell, R.M. 1994. Swelling of wood, part II. Swelling in organic liquids, Holzforschung, 48, 480-490.

Nakagami, T. and Yokota, T. 1983. Estimation of crosslink-formation among wood components by dimesional stability merasurements. Mokuzai Gakkaishi, 29(3), 240247.

Netscher, T., and Bohrer P. 2002. Towards Highly Activating Leaving Groups: Studies on the Preparation of Some Halogenated Alkyl Sulfonates, Molecules, 7, 601-617.

Nordstierna, L., Lande, S., Westin, M., Karlsson, O., Furo', I. 2008. Towards novel wood-based materials: chemical bonds between lignin-like model molecules and poly(furfuryl alcohol) studied by NMR, Holzforschung, 62, 709-713.

Rowell R.M. 2005. Handbook of Wood Chemistry and Wood Composites, ISBN: 9781-4398-5380-1, CRC Press, Boca Raton, Floridai, USA.

Rowell, R.M. 1984: Penetration and reactivity of cell wall components. Chapter 4, p. 175-210. In: Rowell, R. M., ed. Chemistry of Solid Wood. Adv. Chem. Ser. 207. American Chemical Society, Washington, DC.

Rowell, R.M., and Ellis, W.D. 1978. Determination of dimensional stability of wood using the water-soaking method. Wood and Fiber, 10(2), 104-111.

Schirp, A. and M.P. Wolcott. 2005. Influence of fungal decay and moisture absorption on mechanical properties of extruded wood-plastic composites. Wood and Fiber Science. 37(4), 643-652.

Schneider, M.H., and Brebner, K.I. 1985. Wood-polymer combinations: Bonding of alkoxysilane coupling agents to wood, Wood Science and Technology, 19, 67-73.

Storey, R.F., and Sherman, J.W. 2002. Kinetics and mechanism of the stannous octoate-catalyzed bulk polymerization of $\varepsilon$ caprolactone, Macromolecules, 35, 1504-1512.

Wiltshire, J.T., and Qiao, G.G. 2006. Degradable core cross-linked star polymers via ring-opening polymerization, Macromolecules, $39,4282-4285$. 